\title{
CONSTRUCTING ALIEN SPACE IN SOUTH SLAVIC ORAL LYRIC
}

\author{
Ana Vukmanović \\ Independent scholar, Serbia \\ e-mail:ana.vukmanovic@hotmail.com
}

\begin{abstract}
The paper discusses alien space as a construct whose meanings are variable and depend on the assumed perspective, context of singing, and human relations. Alien space is constructed in South Slavic oral lyric as a space of the Other or as the other (liminal) space. The analyzed songs show tension between the alien and own worlds. The alien spaces are marked by relations of alienness and neighborliness. These relations are changeable and limited by the period of the ritual. The ritual context of songs and the ritual inversions of meanings and order make the spatial constructs complex. Oral lyric dominantly subjects the locus to the characters, whereby it has an attributive function. The songs make an analogy between the alien space and the Other. They model alien spaces as unknown, far, fantastic, wild, and dangerous, and as places of death. The paper deals with liminal zones as radically alien. These zones connect or separate own and alien spaces, enabling communication between them. The alien space is constructed as dominantly non-homogeneous and unintegrated, and as such it is an ample reservoir of meanings in oral songs.
\end{abstract}

Keywords: alien space, center, construct, the Other, periphery, ritual, South Slavic oral lyric songs

\section{INTRODUCTION}

This research of alien space was carried out on the basis of the corpus of representative anthologies and collections of South Slavic oral lyric. The reliability of sources was ensured by the academic integrity of editors (Българска народна поезия и проза в седел тола, Българско народно творчество в дванадесет mола, Slovenski narodni pesni, Hrvatske narodne pjesme, editions of the Institute for Literature and Arts in Belgrade) and of those who gathered the songs (Vuk Stefanović Karadžić, Franjo Ksaver Kuhač, I. S. Jastrebov, P. A. Rovinski).

Traditionally, South Slavic oral lyric songs are classified into ritual-costume songs, ${ }^{1}$ labor songs, religious songs, and love and family songs (Nedić 1977: 9-27). However, oral lyric songs are multifunctional and therefore the same 
song, in different contexts, can be classified differently. For that reason, research was carried out on songs of various genres, which are relevant for the topic of spatial construction. During the research it was noticed that the basic models of alien space emerged with similar functions in different genres. It was also noticed that all the models did not emerge in all genres. The way of spatial construction depends on the function of the song and the context of singing. For example, the other space as a space of the dead is typical for laments, and as a liminal zone for the wedding songs. Within the same genre, as in wedding songs, the space of the Other is modeled at different levels (as unknown, faraway, strange, wild, dangerous). Different models of the space of the Other, besides in ritual-costume songs, can be found in love songs as non-ritual.

The research results presented in this paper are based on the representative corpus of South Slavic lyric songs. However, insight into a larger corpus could reveal some new variants of the models of the alien space.

\section{THE NOTIONS OF SPACE}

In oral lyric the notions of space as a fundamental cultural category are formed within the joint activity of the community. During this process, they distinguish between the ritual space and profane space, at the same time also referring to them. Relying on perception, experiences, and adopted cultural models, the singer, when singing, models the space through which he or she moves, or in which he or she resides, humanizing it, thus creating his or her own world. More precisely, the space exists only through the human point of view (cf. Lakoff \& Johnsen 2003 [1980]: 166). Relations to it are complex and ambiguous, and they depend on the function of the song (the context of singing, the assumed perspectives, the relations established in space) and the person's position in it. According to this, the same places acquire different, even opposite, meanings. Within these processes, they are formed as non-homogeneous and are divided into limited/unlimited, closed/open, near/far, and own/alien places.

Fluid meanings reflect the cultural dependence of spatial models. That dependence can be observed in the relations between the center and the periphery, which are revealed as dynamic. For example, the center of the wedding ritual is in the groom's house on which the ritual is focused, since its aim is to bring the daughter-in-law to the new home, but wedding songs can adopt a female perspective and then house is the farthest periphery, an absolute distance on the other side of the mountain or across the water. A human always reveals the center and the periphery as constructs, essentially determined by the human attitude towards them. 
During outsinging, within the same song, the change in the spatial model can be followed. The songs of rejection ${ }^{2}$ intensify the own/alien relation. The bride's family drives away the wedding guests, stressing that the maiden and the land are alien to the guests (Yastrebov 1886: 401). In this song, spatial models are complex because, in the appeal to the wedding guests, the bride's family first takes their perspective, marking their own land as alien, and then they arrogate it to themselves as their land. Through the parallelism, the maiden is associated with the space, and according to that she is defined as alien to the guests and ours to her family. Since the wedding songs are a part of the ritual, during further development of the ritual situation in this song the space briefly changes the master, because the wedding guests occupy it and in that way they get the maiden. When they place the wedding banner in the bride's yard, they occupy the alien space and organize it because from their perspective it is alien, irregular, and chaotic (cf. Eliade 1965: 35). When they leave with the bride, the power over the house reverts to the previous order. ${ }^{3}$

\section{OWN SPACE: THE PERSPECTIVE OF THE OTHER}

When the own world is organized from the perspective of the Other, the spatial construct is emphasized. When the queens ${ }^{4}$ as beings from the distant, ethereal world go around in the village, from one house to another, enter the houses and sit around the dining table (Karadžic 1975: $\left.159^{\circ}\right)^{5}$, they by their movements connect the village, thus performing the magical encirclement, establishing boundaries. Their alterity, which is ritually temporary, is connected with the ritual space and type of landscape, with the ideal land. At the same time, they change the houses and the village where they arrive by ritual acts (cf. Zielinski 2006: 58-59). In fact, the queens themselves as ethereal beings construct the human world during the period of the dual meaning of the ritual period. In that way the village remains a human place, but within the inverse sacred order, it identifies with the distance as well. The farthest distance of the queens' land is getting closer to the human center (dining table) and together they form a spatial construct - all boundaries are temporarily destroyed in the ritual, the positions of the center and the periphery are relativized. The village remains a microcosm during the ritual, but the power of the order comes from the periphery, from the queens' land. ${ }^{6}$

Spatial and personal ambiguity is reflected in the fact that the participants in the procession are village girls and liminal, unworldly beings. They are the Other, different, fantastic, unrecognizable newcomers (cf. Waldenfels 1997: 20). The song refers to them as unmarried, unknown maidens (Kuhač 1941: 272), 
but also as the maidens ready to be married, who pass through the pre-wedding initiation (cf. Kovačević 1985: 129). The ritual order itself considers them as from some other place, even if they appear in their own house, in their own world (Waldenfels 2006: 15). The spatial aspect of alienness is implemented more clearly through the other village from which the bride arrives (Karadžić 1975: $27^{\circ}$ ). These are the reasons why the alienness is thought of as an alien place, as other space, as a place outside the system (Waldenfels 1997: 12). From that specific position, the Other is positioned, in rituals and ritual lyric, as somebody from here, and from far away, from inside and from outside. The queens and newlyweds are simultaneously outside their milieu and inside it (cf. Waldenfels 2006: 112).

\section{ALIEN SPACE AS IDEAL}

Semantic spatial inversion reflects the processes of social and poetical construction not only in constructing the own space from the perspective of the Other, but in constructing the alien space as ideal. Within the spring rituals, the unworldly land of queens is described as ideal. The queens sing to the young woman that they will take away her child if she refuses to pay ransom for him. They will take him to their own land, where two suns are shining, two winds are blowing, because they need him as the basil (Karadžić 1975: $176^{\circ}$ ). The same principle is applied in the construction of the groom's land at the wedding. The bride is asked to come to the groom's land where it does not snow, but only mild rain falls, like summer dew (Karanović 1990: 11º). Both songs stress the fertility and richness of the ethereal world, marked by doubled sun and mild rain, contrasted to the construct of dangerous alien land, which implicitly exists in the traditional culture. Ritual and mythic meanings of the two suns point to the day (celestial) and night (subterranean) orbit of the Sun (cf. Eliade 1958: 136), establishing the vertical solar-chthonic. In that sense, the ideal place merges two worlds. If the songs are compared, the groom's land becomes other-worldly, similar to the land of the queens, and he and his family become analogues to the participants in the ritual procession, which correlate with the common notion of wedding guests as arrogant and mighty (Lilek 1898: 25).

The idealization of the groom's land is performed from the position of culture. The patriarchal community represents it in the songs as more beautiful than the bride's land, as an organized world, symbolized by arranged tables, adorned with golden strings, covered with silver cloths, around which noble mothers- and fathers-in-law sit, as well as the brothers-in-law who are maritime merchants (Karadžić 1975: $5^{\circ}$ ). Although the maiden sings the song, the male, alien space 
is presented as central. Wedding inversion rescinds the distance, and alienness is neutralized by idealizing the patriarchal community. The bride takes the perspective of the new family: by giving priority to the new house, she parts from her own and starts the ritual phase of aggregation.

\section{ALIEN SPACE: LEVELS OF CONSTRUCTION}

Contrary to the semantic inversion, the construct of own/alien space usually corresponds to the oppositions good/evil, and safe/dangerous. The processes of the spatial construction can be traced in the acts of organizing the world. Just when the human, in the cultural process, builds up his or her residence and fences it, the water, forest or mountain can become external, alien, and hostile. These characteristics are not imminent to them. The perception of the external space is permanently penetrated by intuition (cf. Cassirer 1955: 104). As the notion of the world is performed from the first person's point of view, Husserl (as cited in Waldenfels 1997) shows that here forms the zero point on the basis of which the spatial system is formed, including the relations of the center and alterity/alienness. The relation "I am there where you are not" represents the relativity (spatial - A.V.) of the alienness (Waldenfels 1997: 194-195).

On the other side of the border there is somebody else's, alien world. It is open but limited as well, determined by crossings and obstacles, relations of neighborliness and alienness (Waldenfels 1997: 195). The alien space as a space of the Other can be human or inhuman, but it is always organized in a way, and analogous to the cosmos. It is encoded twice - it is determined by relations of closeness and distance, known and unknown, one's own and someone else's. ${ }^{7}$ On the other hand, the alien can be the other space. That other space can be a land of the dead or a liminal zone. In both cases it is mainly inhuman, opposed to the own space, as well as the space of the Other. As the radically alien, they are outside the order; a non-place cannot be registered in the network of places and it shows inaccessibility of a radical kind (Waldenfels 1997: 187).

The opposition "the space of the Other / other space" can be noticed in the example of the wedding songs. Although the bride's and groom's houses are essentially different, the difference is established through the opposition own/ alien, which depends on the perspective and in fact is built on the principle of "symmetry of the mirrors" - alien space has the same structural characteristic as one's own, but their direction is opposed, so they can be seen as isomorphic (Karanović 2010: 150). However, wedding songs, during the liminal phase of the ritual, have the need to stress this otherness, even when the groom's land is modeled as ideal. Ritual acts of the bride's separation from her home and 
of her adoption in the new one (saying good bye to the hearth / salutation to the hearth - Đorđević 1984 [1923]: 268; Čajkanović 1994a: 154) refer to the existence of the two worlds that are occasionally different. An especially emphasized position of one's own and the announcement of the possible change within the pair "one's own / alien" appears when the maiden in the song asks for forgiveness - she asks her family to let her go, to leave the home, as well as the golden table as a center and a symbol of her old world (Nikolić 1888: $7^{\circ}$ ). In order to arrogate the alien, groom's world, the bride needs to be separated from her own during the separation phase of the wedding.

Alien space as a space of the Other in South Slavic oral lyric is constructed at different levels: as unknown, faraway, strange, wild, and dangerous.

\section{ALIEN SPACE AS UNKNOWN}

Oral lyric constructs the alien space as primarily unknown. A young man sings about a horse which brought him to the white castles, fenced with pine trees, where the maiden lives. She sweeps the castles with a little needle traditionally used for embroidering handkerchiefs (Karadžić 1898: 466 ${ }^{\circ}$ ). He arrives in an indefinite - someone's - world situated in the pine forest, which points to the inhuman nature of the castle. Alienness is alleviated by the attribute white, which gives it the characteristic of lightness. However, white can be associated with the incorporeal, in which case the castles would be radically other-worldly (cf. Radenković 1986: 8-11). This ambiguity of the attribute marks the alien space as ambiguous as well. When the unknown maiden sweeps the floor, she organizes the world. Her castles are somewhere else, but it is not outside the order - the order can be recognized, and the young man places it in a particular system where the wild, open (pine forest), and the own, fenced (swept castles), are juxtaposed. The ambiguous notion of alterity (in this case - the alterity of the maiden) is formed by the spatial code.

The unknown space is connected with the motif of abduction. When the young man abducts the maiden, he takes her to his world, which is distant, alien, and unknown to her. The maiden enters the garden and falls asleep among roses and carnations. The young man comes to mow, sees the maiden, leaves the scythe, steals the maiden, and takes her to the alien, unknown green mountain (Osinin \& Burin 2006: $347^{\circ}$ ). While the maiden is passive (sleeps, and then she is an object of abduction), the young man actively establishes a relationship with two spaces - he mows the garden, organizing the world, and takes away the maiden into the green mountain, disturbing the social order. He moves through the human, fenced, own garden, and through the inhuman, open, wild mountain. The 
mountain is unknown to him as well, but it is accessible. This kind of complex relation between the young man and the locus corresponds with the fact that he, in the liminal phase, crosses the boundaries between the own and the alien easily, because he belongs to both spaces, or does not belong to any of them.

\section{ALIEN SPACE AS FARAWAY}

On the second level, the alien space is far away. The distance is constructed by the human perception of the physical (corporal) capabilities (Mršević Radević 1996: 397). It is different from the place where we stand, and the songs construct the notion of distance in contrast to the house as a close place (Maltsev 1989: 141). As unknown, the other man is alluring but dangerous - in the same way the distance is the space of longing, which should be conquered and tamed, and the dangerous space where the man should protect himself. The formula at the distance, which is the poetical "trigger" for the existential and ontological uncertainty of the liminal situations, carries a semantic potential of alienness.

The most typical model of distance is the three-part structure "mountainwater-field". The maiden calls the brother's horses to eat and drink because a long way to the bride awaits them - three high mountains, three deep waters, and three wide fields (Andrić 1929: 255 ${ }^{\circ}$. Besides the distance, this model holds the cosmic dimensions of height, depth, and width, and the wedding guests mark the boundaries of the world by moving through the space. The multiplication of structures represents a typical folklore pattern and stresses the impassableness. Another folklore pattern is number nine. The daughter begs for forgiveness because she is going far away, across nine deep rivers, nine wide fields, nine big mountains, and nine villages to arrive at the groom's - the tenth - village (Ivanova \& Zhivkov 2004: $397^{\circ}$ ). This variant includes the forth spatial entry, represented by the village, and in it the song deviates from the numerical structure because it emphasizes the tenth village as the end of the ritual journey, which is the space of the maiden's new home.

Since it is hard to surmount the distance, because it is isolated, inaccessible, and unknown, it is also difficult to communicate with it. As it is very far, it is a dangerous space of disappearance (Mršević Radević 1996: 399). A variant of the song about the path of the wedding guests constructs the distance as impassable. It emphasizes the power of the wedding guests over the space, so they gain characteristics of supernatural beings, capable to pass through the mountain, although the deer which belongs to the wild world cannot do it, and to cross the wide waters, which the fish cannot swim across (Štrekelj 1904: $\left.5440^{\circ}\right)$. The hyperbolas are frequent figures in oral lyric. They contribute to 
forming the lyrical world, expressing feelings; they are the recourses of lyrical fantasy, and in this case they emphasize the capability of wedding guests - the spatial construct itself is subordinated to that function. ${ }^{8}$

Distance is constructed by temporal models as well. The horse needs a day for gaiting, the hero two days for walking to reach the maiden's land (Rajković 1869: $141^{\circ}$ ), or the journey takes three days across the field and four across the sea (Petranović 1989 [1867]: 183º), or the maiden is forty overnight stays far from the young man (Andrić 1929: $281^{\circ}$ ). Temporary coding can be combined with the spatial one: the hero rides a horse through the mountains, he travels and hunts for three days and eventually he hunts down the maiden (Miladinov, D. \& Miladinov, K. 1961: 599). The mountain is a symbol of the other, chthonic, inhuman space. As emphasized, its distance marks these characteristics. The maiden as a catch, as a wild being, becomes an alteration of space. She is different from the young man because her residence is inhuman, far from the young man's world. The spatial code is dominant, so the maiden's otherness is not alleviated by adornments.

The image of the circular growth of the sour cherry tree forms a special spatial model from a temporal perspective. The sister-in-law consoles the maiden who awaits the wedding and tells her that the sour cherries were planted when her future husband's family visited her home for the first time; when they came to ask for her hand, the sour cherries were in blossom, when they came to take her away, they were eating sour cherries (Karadžić 1975: 414º). The cycle of growth of the plant corresponds to the maiden's life cycle, more exactly to the phase of the wedding as a ritual of passage. The construct of the distance is determined by emotions: the maiden's fear and the sister-in-law's tranquility. Uncertainty increases the distance, and the position of acceptance of the new house as one's own disparages it. The relation between two sisters-in-law dynamizes the meaning of the distance, and implicitly positions the two houses both in spatial and ritual sense.

The notion of distance is constructed by activating the symbolic potential of water. Ethnographic material records that the Serbs did not easily give away their daughters across the water even if that meant only a rifle range distance from the house (Popović 1950: 261). This note confirms that the distant space is a construct, that has just loose connection to the physical reality. The differentiation of the space by establishing boundaries is conducted by human emotions in the encounter with the Other (cf. Cassirer 1955: 95). The water does not have to be a less known space, but it certainly is different than the village and the house. When the wedding song is sung from the maiden's perspective, wedding to the distance is condemned, and it is marked by the sorrow of the family who loses one member, as well as of the maiden who leaves the house and cannot get 
over the fact that her mother gave her away to the distance, across the Danube River (Bušetić 1902: $82^{\circ}$ ). Different emotions follow the wedding and merge with the motif of a dangerous passage, which becomes the sign of the change.

On the other hand, mythical thought rescinds the spatial distance because the distant merges with what is close at hand, thus being essentially the same (Cassirer 1955: 91). This is the case in the song that speaks about the falcon that flies through a narrow gorge. When the falcon asks if the maiden's castles are far away, it gets an answer that they are neither far away nor close, but the castles are where the maidens are singing and the bread is being baked (Ivanova \& Zhivkov 2004: $292^{\circ}$ ). Opposed to the gorges as clearly wild and hardly passable, there are the maidens' castles as completely pleasant, with the sounds of maidens' songs. They are made cosmic by bread-baking (Ivanova 1998: 9). This kind of ambiguous space - faraway and pleasant - shows that the distance is not fixed. It can be overcome by moving; no matter if the wedding guests are travelling through the wild space or the falcon is flying over it. In this way, the close space is moving away, the faraway one is moving closer, and the hypothetical alien, in certain circumstances, becomes familiar (cf. Karanovic 2010: 150). The usual notion of the bride as a dangerous being from the other world is also a construct, because she is, from this perspective, alien and distant; she is not dangerous, but tame.

Even if the maiden comes from the other side of the boundary, thus being clearly from the other world, she can become dear and gladly expected. The young man falls in love with the maiden who is like an iris brought from the other side of the mountain, across the white Danube, and planted in the garden below the privet. A thin and tall fir grows from the iris, from its peak dew drops, from the root the Danube flows (Benovska-Sabkova 2005: 203 ${ }^{\circ}$ ). Potentially a wild, mountain being, arriving from across the water, is now being cultivated through the parallelism with the iris planted in the young man's garden. No matter how much alterity (other-worldliness) is spatially emphasized, it is disparaged by stating love and, by that, human feelings change the nature of the mountain and the Danube. The contrast between the mountain and water, on the one hand, and garden on the other, is annulled in the cosmic notion of a fir tree as axis mundi, which connects three worlds - subterranean, earthly, and celestial, that is, the maiden's and the young man's.

In the ritual song, lazarice $^{9}$ speak with pigeons, inviting them to come in the spring time when the family wishes to marry the son/daughter to the maiden / young man from far away (Veselinović 1890: 72-74). ${ }^{10}$ The positive connotative meaning of the wedding to the distance can point out the advantages of exogamy. When the song emphasizes the positive distance as wild - the girls in a ritual procession sing that if the family does not marry the young man, he 
will escape to three mountains and four turfs, where he will find a maiden and bring her home (Yastrebov 1886: 112-113) - it presents an inverse ritual order. The maiden and the young man, in the liminal phase of the initiation ritual, gain from the distance the power of alien spaces, above all, fertility.

When the different values of distant spaces are compared, the constructed relation to the Other, no matter if it is coded by a personal or spatial code, is shown as complex, potentially contradictory. The other space, as the Other in general, is ambiguous - equally dangerous and desirable.

\section{ALIEN SPACE AS STRANGE}

Strangeness is the third level of alterity. It is not only unknown to the people, but also unintelligible. However, a strange young man is not necessarily undesirable. An inverse spatial model is constructed: the strange hero passes the village, dressed in strange clothes. He wears a Hungarian belt and carries Turkish knives. He asks the fair maiden to lead him out of her village, to the green mountain (Popović 1888: 21, $1^{\circ}$ ). The local, organized village is unknown to him. In order to surmount the space, he needs help of the village girl, alien to him - maybe strange. He wishes to go out to the open, wild, green mountain. Strangeness formed by the ethnic code originates from the more recent times (the ethnicity of the young man is not clear). The perspectives intervene and reveal mutual strangeness: from the perspective of the villagers he is strange, from his own perspective - the village is impassable. The flexibility of the construct of one's own and alien is necessary for communicating with the Other, for the young man and the maiden to get in touch. Just when the polycentric world exists, there is a possibility of understanding.

\section{ALIEN SPACE AS WILD}

The wilderness represents the fourth level of the alien space. The maiden grew up in the wild space, in back of the mountain, below a poplar (Rovinski 1994: $511,2^{\circ}$ ). Although she comes from the other side of the boundary (mountain), and because she is other-worldly, the maiden knows the human world of dancing songs. She participates in the sacral/profane decoration of dancers with poplar leaves. In contrast to the previous song, where the mountain is unknown to the young man, in this one the opposition between one's own and alien is relativized since both - the open space in back of the mountain and the village - are familiar to the maiden. The wilderness, as well as the distance, although inhu- 
man, does not necessarily need to be marked negatively: the space behind the mountain, below the poplar, is tamed by a possessive adjective (my) so that the maiden, although alien, is to be the young man's maiden.

As distant and wild, the space possesses special powers. In lullabies the space is apotropaic. The mother sings to her son, wishing him to fall asleep. She is telling the story of how the mother gave birth to him in the mountains, among wolves; a white fairy was the midwife, a she-wolf cut his umbilical cord, and a doe nursed him with milk (Rovinski 1994: 514, 11 ${ }^{\circ}$ ). As the child was born in the mountains, he gained the powers of the wild world, for example, the strength of wolves. He received the strength from a doe's milk as well. Since the fairy was the midwife, he would be under her protection, and he is thus transformed into a half-demonic being. The magical function of the lullaby constructs the notion of desirable wilderness, and the opposition human/inhuman is not determined by value. If it were, then the inhuman, alien world would be mightier than the human.

\section{ALIEN SPACE AS DANGEROUS}

Danger represents the fifth level of alterity. The dangerous space is, above all, modeled by incantations. ${ }^{11}$ Their spatial model is subordinated to the function of protection from the evil forces, demons, and illnesses, which they drive away to the wild places. The weed - the white Saturday, the sister of hail, fell in the field and there let the hair grow to cover the field. The incantation says that the field is no place for her, that she has to go to the bleak mountain, into the deep water, where there are no people, where the rooster does not crow, hens do not cackle, oxen do not moo, and sheep do not bleat (Yastrebov 1886: 175). The human, cultivated space of fields is opposed to the wild, unfertile spaces of the mountain and water. The incantations model wilderness as radically inhuman, soundless. Not only do humans not live there, but it is a residence of dangerous forces and demons.

Contrary to incantations, the lyric song transforms the groom's land into a demonic, and therefore dangerous, place. The maiden was given away to the ninth village, across nine high mountains, nine green forests, nine big rivers, and nine cold fountains - where roosters did not crow and lambs did not bleat (Yastrebov 1886: 216-217). The wedding leading to the voiceless spaces corresponds to death. The formula of a black mountain activates negative connotative meanings and emphasizes the impassableness of the mountain, which the maiden cursed because her mother married her to the distance against her will (Andric 1929: $231^{\circ}$ ). Periphery is dangerous for the bride and for the groom, 
but on this occasion hostility towards that space is transferred to the other alterity - to the new house. By cursing the mountain, the bride endangers the fertility of the new family.

The image of the completely impassable forest in the song stresses the danger. The maiden is asked to drive away wolves through the thick forests. She answers that she is afraid, that her hair is long and gets tangled in blackberry and raspberry bushes, and in Peter's apple (Jovanović 1926: 52, $1^{\circ}$ ). It is expected that the maiden, whose name is derived from the noun 'wolf' (in Serbian: Vukavuk), should have power over wolves. Like wolf men, ${ }^{12}$ she needs to drive wolves away and protect the village. ${ }^{13}$ Nevertheless, she denies having this power. The fear of wild animals is constructed by the wild space, more precisely, by thorny plants in which the maiden's hair is hooked. The final verses move the spatial code from wild to tame, and by that the symbolism of the wedding and love in the song is strengthened. Contrary to the dangerous space of the forest, the apple appears in it. Although the maiden's hair is hooked in it as well, the apple is qualitatively different from blackberry and raspberry, because as a fertile tree, it belongs to the organized human world (Radenković 1986: 198).

Especially dangerous places are marked by taboos. The young shepherd cries out to the maiden not to drink cold water from the well in the green mountain because fairies bathed the child there and poisoned the water (Kuhač 1941: $274^{\circ}$ ). The taboo protects the maiden from the poisoned water, but protects the sacred place from the maiden as well. When the well gets in contact with a demonic being, it becomes sacred. Only in a specific context the spring is dangerous for the people who belong to the profane sphere. When we think about the spatial construct, it is important to pay attention to processes of formation of the spatial complexes: spring - tree, spring - fairy's ring, river bridge, river - water mill, river - fish (Bandić 1980: 263) or mountain - well. Within them, the spatial image is widened and the coordinates of one (sacred) world are established.

The alterity is not dangerous just for the maiden, but for the young man as well. When he sets off for the bride, he begs for forgiveness and blessing from his mother since he will go to the alien village, for the alien sister - his beloved (Karadžić 1975: $27^{\circ}$ ). The complex of alterity is formed out of place and being. While the space of otherness remains alien, the alien sister is transformed into the young man's beloved. In that process she is arrogated, adopted in the young man's own world, because the ritual passage needs to be carried out. The groom does not arrogate the space, and it is not transformed. It remains dangerous and for that the young man needs special protection of blessing on the road through the alien land. The space remains the same after the wedding ritual. 
The tension between one's own and alien is modeled by relations between sexes. When the mother worries that the maiden will lure her son, the son answers that the maiden will not lure him because she carries water from his well, picks the flowers in his garden, lauds the wreath in his chambers and puts it on his bed (Osinin \& Burin 2006: $189^{\circ}$ ). The young man acquires power over the maiden during her stay in his space, the house, and the garden. In other words: the maiden loses her powers when she enters the alien space. From this position, the space is constructed as a magical remedy/weapon, which provides victory for the young man in the love game and, in a broader sense, in human relations. When the maiden enters the young man's yard and garden, and even the bedroom, she becomes his. One's own space tames the alien being.

\section{THE DYNAMIC OF SPACE}

Oral lyric expresses the spatial dynamics by modeling images of movements. The road represents a specific topography of boundaries (Ivanova 1987: 80). When the maiden parts from her family because the alien brothers take her away, her brothers accompany her to the enchanted mountain, to the cold water, and to the white castles (Karadžić 1973: 60). Although the image presents the separation ritual, the song constructs a complex of porous boundaries. Her brothers succeed in surmounting the mountain and the water as hard boundaries between two worlds, and arrive in front of the groom's white castles. There they stop. The occasional porousness of the mountain and the water shows the instability of the construct, but it emphasizes the otherness of the groom's home, which is, in this context, more radical than the wild interspaces. The pair brothersin-law / her brothers points to the ambiguous model of the road - while the brothers-in-law are the guides during the ritual passage, her brothers are an escort which provides protection of one's own world and represents a temporary resistance to the new reality. Both of them follow the same path, but for the groom's brothers it is a return to the known, whereas for the bride's brothers it is the path of the final separation, emphasized as the other and wild. The dynamic of the space is reflected in passages which change the man, but the space is changing itself as well. When the brothers accompany their sister-bride across the mountain and water to the white castles, and when they separate from her in front of the groom's house, they pass over the cosmic boundaries. From unmarked young men they become liminal beings - guides. The maiden, whose otherness is emphasized, is changing as well. When she enters the new house, she is finally separated from her family, she is not a part of it anymore, but of the other family, she is not a sister/daughter, but a sister-in-law / wife. 
The brothers become the others, and within the new order the brothers-inlaw, by that moment alien brothers, become hers. The spatial model shows the changes of human relations, above all, because the bride has changed. The maiden's passage inverts the nature of the space - the groom's (white) castles, initially alien, become her own.

Although the mountain is dominantly unearthly and dangerous, the ambiguity of the spatial construct enables the activation of contrastive meanings. Opposite to the dangerous and wild mountain, there is a fertile apple mountain. When the wedding procession leads the bride across the mountain, apple trees grow there; when the bride crosses the water, it flows with wine, and the village that she enters is a happy, healthy place (Karanović 1999: $23^{\circ}$ ). When, as in this song, fertility and creation of the new family are emphasized, the locus makes the bride a powerful being, who tames the unearthly world, bringing prosperity to the new family.

\section{THE OTHER SPACE}

While the mountain/road is stressed as liminal and inhuman, the notion of the other space is modeled in the song. That other space is opposite to the space of the Other. The typical other space is the boundary. The boundaries establish the institution of the zone (no man's / every man's land). They are sacred to the inhabitants of the territories around it, and the man who is in the zone hovers between two worlds (Van Gennep 1981 [1909]: 24-25). The zone establishes relations with other spaces, one's own and alien, it does not belong to either of the worlds that it separates, and in this way its otherness is emphasized. The lyrical songs model the separation of the liminal world from the human one by the motifs of the high mountain, deep water, and wide field. Liminal space is inversed in relation to the human world and different rules apply in it (Turner 1969: 167). For that reason, the maiden can be active on the road and, for example, ferry the wedding guests across the sea, and show herself as a master of the water (Karadžic 1975: $74^{\circ}$ ). When the groom or the bride crosses the water (sea, river, bridge) or mountain (forest), their otherness and inhumanity are additionally marked.

As much as the bride's home is alien, even unworldly to the groom (or the groom's home to the bride), this alterity and otherness are human, and by that essentially different from the meaning of the road as inhuman. The road, marked by the mountain and water, does not have any mutual characteristics with the house - it is no man's domain. It is especially marked because in the mythopoeic image of the world it connects two contrasted, mutually distant 
spatial points, no matter whether it is orientated horizontally or vertically (Detelić 1992: 111).

The meadow, valley, or field represent the first part of the road, the one closer to home - they are partially organized, yet uninhabited spaces. They are limited, but have ambiguous meanings. In them, a wedding procession can get in touch with good as well as with evil forces (cf. Detelić 1992: 46). When it moves away from the house, it arrives in the mountain spaces, which are dangerous and unorganized, associated with demons, and therefore contrasted to the home. Because of that, they are unfriendly to man, chthonic and alien. In chromatic code, green is the color of the first phase of the journey, and black is the color of the second phase. The colors in the process of cultural coding gain abstract meanings of the sign (Karanović 2010: 148).

The mountain is the most typical construct of the interspace. It is inhuman to the utmost and does not have any similarities with the house, even if it is an alien house (e.g. the groom's house). Its danger is constructed by taboos. The mother advises her daughter not to tease the mountain when she passes through three green mountains - one ash tree and two fir tree forests, not to let the horse wet the hooves when they cross the water and not to raise the dust on the road (Yastrebov 1886: 357). If she does not tease the mountain, the maiden respects the speaking prohibition. She does not draw the attention of impure forces, demons, and spirits, who live in that space, to herself. If the horse does not wet the hooves, it will not set the natural power in motion. If the horse does not raise dust on the road, they will pass through this liminal space unnoticed. The multiplication of spaces and emphasis of impassableness by the motifs of fir and ash forests additionally mark liminal, wild space. The three-part model of the forests is part of a more complex three-part model "mountain - water road", and it establishes order in the inhuman, alien world. The result of this is that the interspace, even if it is alien, is not necessarily the same as chaos.

The next song models the ritual ordinance of covering the bride. The maiden asks the godfather and Saint John to put a veil over her head because she is going to pass through the thick forest of lilies. The wind blows and it uncovers her (Arnaudov \& Vakarelski 2004: $387^{\circ}$ ). The uncovered, beautiful face in the chthonic space attracts spells and impure forces, which can bring death to the maiden (Van Gennep 1981 [1909]: 241). The ritual act of covering the bride forms the notion of a mountain as a dangerous and wild place. This poetic modeling of the ritual shows that a spatial construct can be formed by different codes (in this case by action code).

One liminal place does not always have the same meaning. The meaning depends on the spatial model and the function of the space in the song. When the image is set between two mountains, between two cold waters, where the 
maiden fell asleep, laying her head under the rock where a snake is hidden (Miladinov, D. \& Miladinov, K. 1961: $235^{\circ}$ ), the danger is even bigger because the spatial liminality is doubled - the mountain itself is liminal, but the passage between the two mountains is situated between two boundaries. While the danger is only indicated in the previous example, here it is clearly marked by the motif of snake. The peril is emphasized by both the locative code (by the chthonic mountain) and the zoomorphic one (by the snake as a chthonic being).

\section{THE SPACE OF THE DEAD}

The world of the dead in laments represents the culmination of alterity. It loses ambiguity and is completely inhuman and evaluated as negative. It is a far space where roads without return lead (Karadžić 1975: 151), from where no man can ever arrive (Karadžić 1898: $125^{\circ}$ ), because there is no return from that world. It is qualitatively different from the space of the Other in wedding songs, represented by the groom's/bride's home, as well as from liminal zones, from where the man can return safely. As a world of darkness, it is radically opposed to the white world of the living. While two suns shine in the ideal land, there is no shining sun in the town of the dead (Karadžic 1898: 125). Contrary to the width of the fields, there is a narrow and tight space of laments, the space without doors and windows (Karadžić 1975: 153º), which points to the coffin. While the spaces of oral lyric are ample, rich in water, the world of the dead is infertile and arid (Karadžić 1898: $125^{\circ}$ ), or the water in it is dead and chthonic (Karadžić 1898: $126^{\circ}$ ). As the enchanted world of the Other, it is strange (Karadžić 1898: $143^{\circ}$ ), but the meaning of that strangeness is radical since it is not the human world at all. It does not provoke curiosity, but invokes the horror of the laments. It is populated not only with the dead, but with snakes as chthonic beings which drink the eyes of the dead people (Karadžić 1898: $126^{\circ}$ ). The space of death is formed by various codes as a complex construct - marked by human sadness and fear in encounter with mortality.

\section{CONCLUSION: THE SPACE OF THE OTHER AND OTHER SPACE}

The notions of space in South Slavic oral lyric are dynamic and depend on the context of singing and the perspective taken in the song. In that sense it is possible, as in the case of the queens' songs, to model own space from the perspective of the Other. On the other hand, in the inverse ritual conditions the alien land can be modeled as ideal, when the perspective of the Other is taken 
once again. As it is shown, liminal space is not homogenous and integrated, but differs from one's own space in the way that depends on whether it is the space of the Other, a liminal, inhuman zone, or the land of the dead. In the first case, it can be conquered and then its structure is analogous but inverse to the structure of one's own world. The space of the Other can be unknown, faraway, strange, wild, and dangerous. It is always connected with one's own space and often constructed as its reflection in the mirror (Karanović 2010: 150). In the second case, the liminal space can be surmounted, but remains open and amorphous. The other space, regardless of whether it is the liminal zone or the world of the dead, is qualitatively different than the human world. Spatial dynamics is established not only poetically, but by the change of the perspective, by the movements of heroes and heroines. The lyrical alien spaces represent discontinuity and understand the tension that oral lyrics do not dissolve since their poetics does not require it. Their meanings always depend on changes in people and interactions that people enter with each other and with places.

\section{NOTES}

1 South Slavic ritual-costume songs are characterized by a number of genres. In this paper lazarice songs, kraljice (queens') songs, wedding songs, lullabies, and laments are mentioned.

2 Songs of rejection are a genre of wedding songs. They are sung when wedding guests arrive in the bride's home, and they have a ritual function to temporarily withhold guests. In that sense, songs are analogous to a locked door and different kind of barriers that await wedding guests (Ajdačić 1998: 222).

3 The imagined value difference our land-alien land (the land of the Other) does not require that the Other accept that distinction. It is enough to set the boundary, which in the song is represented by sticking the banner in the yard. People start to fill the alien space beyond the own with different suppositions, associations, and fictions (cf. Said 1979 [1978]: 54). In the lyric songs the meanings of these suppositions, associations, and fictions vary from fear and resistance to desire and welcome.

When the insights of the post-colonial theory are used, it is done knowing that there are limitations on its application to traditional culture. However, it seems that, for discussing spatial models (space of the Other and other space), these insights are inspiring and useful. Although there are different contexts in question, it is noticed that, above all, in the case of ambiguous attitudes towards the Other and towards the liminal space, there are analogies with the post-colonial understanding of the Other and of the Third space.

4 Queens (kraljice) is a spring ritual that takes place at Pentecost in the form of processions of specially dressed and equipped female groups. Queens' songs are sung during the ritual (Nedić 1977: 16; see also Jokić 2012). 
5 For precise citations, the number of the song in the collection is given in the parenthesis; it is marked by the ${ }^{\circ}$ sign.

6 The queens establish the space as cosmic by encirclement. But when they move through the village, they sing about other spaces, maybe describing the queens' path in the past (cf. Jokić 2012: 67).

7 Like in the oral lyric, where the ambiguous relations with the Other are established, at the end of the twentieth century, space and time crossed to produce complex figures of difference and identity, past and present, inside and outside, inclusion and exclusion (Bhabha 1994: 1). The Other, as well as the place of difference and otherness, is never entirely on the outside or implacably oppositional. It is a pressure and a presence (Bhabha 1994: 109).

The figures of the Other in the modern world and in the traditional culture have some similarities but they are significantly different since the alterity in a ritual context is temporary and in a post-colonial context it is permanent. The identities of the participants in the ritual (bride, groom, queens, lazarice, etc.) are marked by temporary difference regarding the community. During the ritual, they exist between the past (previous stage of their lives) and the present (new position in the community). The ritual is a point of change when they cease to be what they were and gain new social roles. They are excluded and are members of the community at the same time (Van Gennep 1981: 37). The heroes and heroines of the ritual-costume songs have the same existential status.

The space of the Other in oral lyric is also ambiguous and depends on the perspective. The other space, although opposite, is in interaction with the own space in the traditional world image. They establish relations based on analogy rather than on contrast.

8 The verses that emphasize the maiden's power to surmount the distance have the same function. The maiden, barefoot and bareheaded, passes as a man through seventyseven towns covered by snow, which stand in her way (Rajković 1869: $5^{\circ}$ ).

9 The lazarice, as queens, are a female ritual group, who go in procession around in the village on the Lazarus Saturday, before Easter. The lazarice songs were sung during the ritual (Nedić 1977: 14).

${ }^{10}$ In a variant, water is a symbol of distance. If it is meant to be, the family will marry the son to the maiden from the distant land situated across the cold water (Popović 1888: $25,2^{\circ}$ ).

${ }^{11}$ In this case, in a comparative context, the attention is drawn to the spatial model in the incantation as well. Based on the function, the spatial model in the lyric song and in the incantation are contrasted. The incantation is singled out because it has a structure similar to that of the lyric song, and some of the incantations can be found in lyric collections (cf. Petranović 1989: 43º).

${ }^{12}$ Wolf men (vučari) are the male ritual procession that goes around in the village (sometimes wearing masks), carrying a killed wolf or a wolf's skin. The ritual has an apotropaic function of protecting animals and people from wolves (Tolstoi 1995: 460). 
${ }^{13}$ Since the song was classified as queens', at the time when it was written down, it could have referred to the connection with the wedding ritual. The queens' ritual is connected with the wedding initiation, because the girls ready to get married are presented to the village in the queens' procession (Karanovic 2010: 89-90). Wolves could be the groom's male friends (Gura 1997: 126). In that case, it would be requested from the maiden to establish a relationship with the new community by a ritual refusal of the wedding guests. Her denial of capability to fulfill the task would mean the passage to the new family. The apple is another wedding symbol whose ritual potential is exceptional - it is a symbol of the maiden, a gift, and a ritual object (Čajkanović 1994b [1985]: 92-99, 233-236).

\section{REFERENCES}

Ajdačić, Dejan 1998. Žanrovi svadbenih pesama. [Genres of Wedding Songs.] Kodovi slovenskih kultura, No. 3, pp. 218-238.

Andrić, Nikola 1929. Hrvatske narodne pjesme. [Croatian Folk Songs.] Vol. VII. Zagreb: Matica hrvatska. Available at https://archive.org/details/ HrvatskeNarodnePjesmeKnjigaSedmaMaticaHrvatska/page/n1, last accessed on 9 October 2018.

Arnaudov, Mihail \& Vakarelski, Hristo 2004. B’lgarsko narodno tvorchestvo v dvanadeset toma. [Bulgarian Folklore in Twelve Volumes.] Vol. V. Obredni pesni. [Ritual Songs.] Varna: LiterNet.

Bandić, Dušan 1980. Tabu u tradicionalnoj kulturi Srba. [Taboo in the Traditional Culture of the Serbs.] Beograd: BIGZ. Available at https://www.scribd.com/ document/64389127/Dusan-Bandic-Tabu-u-Tradicionalnoj-Kulturi-Srba, last accessed on 30 October 2018.

Benovska-Sabkova, Milena 2005. B'lgarska narodna poezija i proza v sedem toma. [Bulgarian Folk Poetry and Prose in Seven Volumes.] Vol. V. Ljubovni pesni. [Love Songs.] Varna: LiterNet.

Bhabha, Homi K. 1994. The Location of Culture. London \& New York: Routledge.

Bušetić, Todor 1902. Srpske narodne pesme s melodijama iz Levča. [Serbian Folk Songs with Melodies from Levac.] Beograd: Srpska kraljevska akademija.

Čajkanović, Veselin 1994a. Studije iz srpske religije i folklora 1910-1924. [Studies in Serbian Religion and Folklore.] Beograd: SKZ \& BIGZ \& Prosveta \& Partenon.

Čajkanović, Veselin 1994b [1985]. Rečnik srpskih narodnih verovanja o biljkama. [Dictionary of Folk Beliefs on Plants]. Beograd: SKZ \& BIGZ \& Prosveta \& Partenon.

Cassirer, Ernst 1955. The Philosophy of Symbolic Forms. Volume Two: Mythical Thought. Transl. by R. Manheim. New Haven: Yale University Press \& London: Geoffrey Cumberlege, Oxford University Press. Available at https://monoskop.org/images/f/ f3/Cassirer_Ernst_The_Philosophy_of_Symbolic_Forms_2_Mythical_Thought. pdf, last accessed on 9 October 2018.

Detelić, Mirjana 1992. Mitski prostor i epika. [Mythical Space in the Epic.] Beograd: SANU \& Autorska izdavačka zadruga. Available at http://www.academia.edu/1378181/ Mitski_prostor_i_epika_Mythical_Space_and_the_Epics_SANU_Beograd_1992, last accessed on 9 October 2018. 
Đorđević, Tihomir 1984 [1923]. Naš narodni život. [Our Folk Life.] Vol. 1. Beograd: Prosveta.

Eliade, Mircea 1958. Patterns in Comparative Religion. Transl. by R. Sheed. New York: Sheed \& Ward.

Eliade, Mircea 1965. Le sacré et le profane. Paris: Gallimard. Available at https://monoskop.org/File:Eliade_Mircea_Le_sacr\%C3\%A9_et_le_profane_1965.pdf, last accessed on 9 October 2018.

Gura, Aleksandar 1997. Simvolika zhivotnykh v slavianskoi narodnoi traditsii. [The Symbolism of Animals in Slavic Folk Traditions.] Moscow: Indrik. Available at http:// inslav.ru/images/stories/pdf/1997_Gura.pdf, last accessed on 9 October 2018.

Ivanova, Radost 1987. Traditional Bulgarian Wedding. Transl. by N. Panova. Sofia: Svyat Publishers.

Ivanova, Radost 1998. Svadba kao sistem znakova. [Wedding as a System of Symbols.] Kodovi slovenskih kultura, No. 3, pp. 7-13.

Ivanova, Radost \& Zhivkov, Todor Iv. 2004. B’lgarska narodna poezija i proza $v$ sedem toma. [Bulgarian Folk Poetry and Prose in Seven Volumes.] Vol. II. Obredni pesni. [Ritual Songs.] Varna: LiterNet.

Jokić, Jasmina 2012. Kraljičke pesme: Ritual i poezija. [Queens' Songs: Rituals and Poetry.] Beograd: Društvo za srpski jezik i književnost Srbije.

Jovanović, Drag P. 1926. Kraljičke pesme. [Queens' Songs.] In: Kićine pesme. [Kica's Songs.] Beograd: Uredništvo Kiće, pp. 49-55.

Karadžić, Vuk 1898. Srpske narodne pjesme. [Serbian Folk Songs.] Vol. V. Beograd: Državno izdanje.

Karadžić, Vuk 1973. Srpske narodne pjesme iz neobjavljenih rukopisa. [Serbian Folk Songs from Unpublished Manuscripts.] Vol. I. Beograd: SANU.

Karadžić, Vuk 1975. Srpske narodne pjesme. [Serbian Folk Songs.] Vol. I. Beograd: Nolit.

Karanović, Zoja 1990. Narodne pesme u Danici. [Folk Songs in Danica.] Novi Sad: Matica srpska; Beograd: Institut za književnost i umetnost.

Karanović, Zoja 1999. Narodne pesme u Matici. [Folk Songs in Matica.] Novi Sad: Matica srpska; Beograd: Institut za književnost i umetnost.

Karanović, Zoja 2010. Nebeska nevesta. [Celestial Bride.] Beograd: Društvo za srpski jezik i književnost Srbije.

Kovačević, Ivan 1985. Semiologija rituala. [Semiology of the Ritual.] Beograd: Prosveta.

Kuhač, Franjo Ksaver 1941. Južno-slovjenske narodne popievke. [South Slavic Folk Songs.] Vol. V. Zagreb: Tiskara i litografija C. Albrecht.

Lakoff, George \& Johnsen, Mark 2003 [1980]. Metaphors We Live By. London: The University of Chicago Press.

Lilek, Emilijan 1898. Ženidba i udadba u Bosni i Hercegovini. [Wedding in Bosnia and Hercegovina.] Glasnik Zemaljskog muzeja, Vol. 10, pp. 5-92.

Maltsev 1989 = Mal'tsev, Georgii. Traditsionnye formuly russkoi narodnoi neobriadovoi liriki. [Traditional Formulas of Russian Non-Ritual Folk Lyrics.] Leningrad: Nauka.

Miladinov, Dimitar \& Miladinov, Konstantin 1961. B"lgarski narodni pesmi. [Bulgarian Folk Songs.] Sofia: B"lgarski pisatel. 
Mršević Radević, Dragana 1996. Srpska frazeologija - jezički okvir za mitski sadržaj. [Serbian Phraseology - Linguistic Frame for Mythic Content.] In: T. Bekić (ed.) Mit. [Myth.] Novi Sad: Filozofski fakultet u Novom Sadu, pp. 395-404.

Nedić, Vladan 1977. Antologija narodnih lirskih pesama. [Anthology of Folk Lyric Songs.] Beograd: Srpska književna zadruga.

Nikolić, Grigorije 1888. Srpske narodne pesme. [Serbian Folk Songs.] Vol. I. Novi Sad: Srpska knjižara i štamparija Braće M. Popovića.

Osinin, Dimit'r \& Burin, Ivan 2006. B'lgarsko narodno tvorchestvo v dvanadeset toma. [Bulgarian Folklore in Twelve Volumes.] Vol. VI. Ljubovni pesni. [Love Songs.] Varna: LiterNet.

Petranović, Branko 1989 [1867]. Srpske narodne pjesme iz Bosne i Hercegovine. [Serbian Folk Songs from Bosnia and Herzegovina.] Vol. I. Sarajevo: Svjetlost.

Popović, Pavao 1888. Kraljice: Srpski narodni običaj o Trojčinu dne. [Queens: Serbian Folk Pentecost Costume.] Brastvo, Vol. 2, pp. 7-29.

Popović, Sreten 1950. Putovanje po Novoj Srbiji 1878/ 1880. [Journey through the New Serbia, 1878/1880.] Beograd: SKZ.

Radenković, Ljubinko 1986. Simbolika boja u narodnim bajanjima slovenskih naroda.

[The Symbolism of Colors in Slavic Folk Incantations.] Književna istorija, Vol. 19, No. 73-74, pp. 3-32.

Rajković, Đorđe 1869. Srpske narodne pesme (ženske). [Serbian Folk Songs (Women's).] Novi Sad: I. Fuks.

Rovinski, P.A. 1994. Crna Gora u prošlosti i sadašnjosti. [Montenegro in Its Past and Present.] Vol. III. Cetinje: Izdavački centar Cetinje / Centralna narodna biblioteka Đurđe Crnojević / Sremski Karlovci; Novi Sad: Izdavačka knjižarnica Zorana Stojanovića.

Said, Edward W. 1979 [1978]. Orientalism. New York: Random House.

Štrekelj, Karel 1904. Slovenski narodni pesni. [Slovenian Folk Songs.] Vol. III. Ljubljana: Slovenska matica.

Tolstoi, N. I. 1995. Vuchary. [Wolf Men.] In: I. N. Tolstoi (ed.) Slavianskie dreunosti: Etnolingvisticheskii slovar'. [Slavic Antiquities: Ethnolinguistic Dictionary.] Vol. 1. Moscow: Mezhdunarodnye otnosheniia, pp. 460-461.

Turner, Victor 1969. The Ritual Process: Structure and Anti-Structure. New Brunswick: Aldine Transaction.

Van Gennep, Arnold 1981 [1909]. Les Rites de Passage. Paris: Picard.

Veselinović, Jovan 1890. Lazarice, srpski narodni običaj u Vranju i vranjskom okrugu. [Lazarice, Serbian Folk Costume in Vranje and Vranje District.] Brastvo, No. 4, pp. 66-94.

Waldenfels, Bernhard 1997. Topographie des Fremden: Studien zur Phänomenologie des Fremden 1. Frankfurt am Main: Suhrkamp.

Waldenfels, Bernhard 2006. Grundmotiven einer Phänomenologie des Fremden. Frankfurt am Main: Suhrkamp.

Yastrebov 1886 = Iastrebov, Ivan. Obychai i pesni turetskikh serbov. [Customs and Songs of the Turkish Serbs.] St. Petersburg: Tipografiia V.S. Balasheva. 
Zielinski, Boguslav 2006. O kategoriji svoj i tuđ u kolonijalnoj i postkolonijalnoj kritici. [On the Category of "Own" and "Foreign" in Colonial and Postcolonial Criticism.] In: M. Maticki (ed.) Svoj i tud: Slika drugog u balkanskim i srednjoevropskim knjižeunostima. [Own and Alien: The Image of the Other in Balkan and CentralEuropean Literatures.] Beograd: Institut za književnost i umetnost, pp. 55-60. 